\title{
TELEWORK IN BRICS: \\ LEGAL, GENDER AND CULTURAL ASPECTS
}

\author{
MARINA CHUDINOVSKIKH, \\ Ural State University of Economics (Yekaterinburg, Russia) \\ NATALIA TONKIKH, \\ Ural State University of Economics (Yekaterinburg, Russia)
}

https://doi.org/10.21684/2412-2343-2020-7-4-45-66

With the rapid development of digital technologies and globalization, telework is becoming increasingly common. For the BRICS countries, the formation of a modern legal regulation model for telework is of great importance. In drafting legislation, it is essential to take into account economic and cultural factors, as well as the need to ensure gender equality. This article presents an analysis of current trends in telework development in the BRICS countries. Its findings reveal various reasons for a growing need to regulate telework. For Brazil, the issue of ecology plays an important role; for China and India, the possibility of integration into the world economy; in Russia, the focus is still on the procedural issues concerning the conclusion and termination of employment contracts; in South Africa, the issue of ensuring not only gender equality, but also racial equality is acute. The analysis gives the authors grounds to conclude that the BRICS countries are still lagging behind the United States and the European Union in the area of telework labor law, despite its widespread prevalence. The BRICS countries do not yet produce the necessary statistics on the prevalence of telework. Issues relating to BRICS's deepening integration require the development of common approaches to regulating the work of teleworkers. The harmonization of legislation between Russia and China is of particular importance due to the territorial factor.

Keywords: telework; teleworkers; labor law; flexible working; BRICS.

Recommended citation: Marina Chudinovskikh \& Natalia Tonkikh, Telework in BRICS: Legal, Gender and Cultural Aspects, 7(4) BRICS Law Journal 45-66 (2020). 


\section{Table of Contents}

\section{Introduction}

\section{Telework in the Russian Federation}

\section{Telework in China}

3. Telework in India

4. Telework in Brazil

5. Telework in South Africa

\section{Conclusion}

\section{Introduction}

The first scientific publications related to the organization of telework date back to the late $20^{\text {th }}$ century, when Jack Nills singled out this new form of labor. The term "telework" or "teleworking" refers to a work flexibility arrangement under which an employee performs the duties and responsibilities of his or her position, and other authorized activities, from an approved worksite other than the location from which the employee would otherwise work.' Currently, more than $88 \%$ of multinational, Forbeslisted companies provide part-time or full-time telework opportunities. The involvement of national labor markets in teleworking is determined by many factors including public policy, legislative regulation, digital literacy, cultural traditions and gender.

The purpose of this study is to compare the legal, gender and cultural aspects of telework in the BRICS countries.

For each BRICS country, we present the data characterizing the level of economic development, population size and peculiarities of territorial development. This information is necessary for a better understanding of labor market trends. Then, we investigate the legal framework of telework. In addition, we try to analyze the gender and cultural factors affecting telework development. As the most important cultural factors, we evaluate overall literacy rates as well as the level of English language proficiency.

When studying telework on an international scale, it seems necessary to distinguish two forms depending on the participants' composition. Under the first form, both the employee and the employer are residents of the same state. In this case, they are subject only to the national legislation. This form of telework is proposed to be called "national telework." In the second case, the employee and the employer are in different countries. This form in this study will be called "international telework."The analysis of the telework vacancy market suggests that the largest telework employers are American companies. These companies offer telework in many countries of the

Telework Enhancement Act (2010) (Sep. 3, 2020), available at https://www.govinfo.gov/content/pkg/ PLAW-111 publ292/pdf/PLAW-111 publ292.pdf. 
world. The situation described shows that in the case of international telework, in addition to the national regulation, the rules used in the employer's country are important. Therefore, it seems important for us to highlight the U.S. experience in regulating telework briefly.

The demand for a detailed regulation of the teleworkers labor was realized in the United States much earlier than in the Russian Federation - in the 1990s on the background of the rapidly developing information technologies. Currently, U.S. legislation is aimed at encouraging the introduction of flexible working arrangements. According to the Telework Report, which is submitted annually to the U.S. Congress, the share of teleworkers in U.S. federal agencies amounts to about $20 \%$ of the workforce. ${ }^{2}$

In the United States, telework is considered the optimal form of employment in the following cases:

- pregnancy, childbirth, breastfeeding;

- if family members need to be cared for (children, older persons, seriously ill persons);

- child adoption.

The active legislation development is now reflected in the Telework Enhancement Act (2010). This law is addressed to U.S. federal executive agencies. The main reason for its adoption was the awareness of the advantages that telework provides for both employees and employers. The U.S. law establishes equal scope of rights, guarantees and obligations for teleworkers and non-teleworkers. The 2014 Presidential Memorandum states,

The federal government's policy is to promote a culture in which managers and employees understand the flexible working arrangements programs available to them. In today's environment, the State must identify and remove any administrative barriers that prevent the use of flexible working arrangements. $^{3}$

Every federal agency in the United States is required to:

- develop a policy whereby workers can telework;

- notify all employees of the agency of their right to telework.

U.S. federal workers have the right to ask an employer to switch to flexible working arrangements. The employer is obliged to examine the request and respond within twenty days. If a refusal is received, the employee has the right to appeal against

2 Status of Telework in the Federal Government (Sep. 3, 2020), available at https://www.telework.gov/ reports-studies/reports-to-congress/annual-reports/.

3 Presidential Memorandum - Enhancing Workplace Flexibilities and Work-Life Program (Sep. 3, 2020), available at https://obamawhitehouse.archives.gov/the-press-office/2014/06/23/presidentialmemorandum-enhancing-workplace-flexibilities-and-work-life-. 
it. The right to telework is not absolute. First, each agency determines a list of jobs where telework is not provided due to the need for the presence of employees. Restrictions can also be imposed based on security requirements. Second, staff members who have disciplinary sanctions for absence from the workplace of more than five calendar days per year cannot be transferred to telework. Third, transfer to telework is prohibited for those employees who have been prosecuted for watching, downloading or sharing pornography in the workplace.

Much attention in the United States is paid to the policy of training teleworkers. The exemption from training is possible only if the employee has sufficient experience and the necessary competences. In order to organize work with teleworkers, the position of Telework Managing Officer has been introduced in each agency. The Telework Managing Officer refers to senior managers and reports directly to the head of the federal agency.

Telework management is based on resource support, which includes:

- written policy;

- control system;

- training system;

- information resources, including cybersecurity;

- resources for telework workplace equipment.

The Personnel Department is obliged to develop a written manual for teleworkers, which should reflect the peculiarities of remuneration and leave, admission to work, dismissal, evaluation of productivity, security, and the procedure for dealing with documents and their storage. All information for teleworkers should be available on a specially created website.

In the United States, much attention is paid to the system of accounting and control in the sphere of telework. Annually, each federal agency submits a report that includes the following indicators:

- the proportion of jobs that can be transferred to telework and the potential number of teleworkers;

- actual number of teleworkers by age and gender;

- management goals in the field of telework and percentage of their achievement;

- teleworkers survey data.

If the total number of teleworkers has changed by more than $10 \%$ compared to the previous year, the federal agency should describe the reasons for the positive or negative change. The report should explain what measures are being taken to identify and remove barriers to the wider use of telework. Based on the results of the reports, submitted by each agency, a general report is formed, which is sent annually to the U.S. Congress. This report provides information on all federal executive agencies and summarizes best practices.

The data analysis from the annual telework reports to the U.S. Congress provides important information to assess the effectiveness of government telework policies. 
It should be noted that the in the United States all cases of telework are taken into account, even if carried out during the year only occasionally. In 2018 , just $25 \%$ of teleworkers carried out their activities without visiting the office; $41 \%$ teleworked for more than 3 days in a two-week period; $34 \%$ did so from 1 to 2 days in a two-week period; and $13 \%$ performed their telework duties not more than once a month. ${ }^{4}$ The report to the Congress noted that the issue of assessing the frequency of telework has traditionally been difficult to measure due to the lack of uniform approaches to calculating teleworkers' working time.

American employers use the following methods of evaluation:

- based on timesheets;

- based on the analysis of the employment contract terms;

- based on automated systems for recording performed work;

- based on sociological surveys.

The U.S. telework accounting system is constantly being improved. Thus, since 2012 all state authorities have been obliged to provide monthly personnel reports, which include indicators of teleworking. We can see that the United States has a sufficient regulatory framework in the field of telework. The U.S. experience is used by us as a starting point for assessing telework in the BRICS countries.

\section{Telework in the Russian Federation}

The Russian Federation is the largest BRICS state by territory, but the country ranks $4^{\text {th }}$ in population, after China, India and Brazil. The number of residents in the Russian Federation in 2018 amounted to 146.5 million people. ${ }^{5}$ By 2030, the projected population will decrease to 138 million. The projected life expectancy will be 66 years. The literacy rate of adults in the Russian Federation is approaching $100 \%$. The official language is Russian. By the level of English language proficiency, Russia ranks only $38^{\text {th }}$ in the world. ${ }^{6}$ English proficiency is thus rated low.

The Russian Federation is characterized by a significant differentiation of territorial development. The most developed areas are the largest megalopolises of Moscow and St. Petersburg, which are characterized by a developed labor market and high pay levels. At the opposite pole are towns, where the number of inhabitants is rapidly decreasing. Such significant territorial differences increase the urgency of creating teleworkers. Telework can be considered to be a way to support smaller towns, rural areas and develop local labor markets.

4 Status of Telework in the Federal Government, Report to Congress Fiscal Year 2018 (Sep. 3, 2020), available at https://www.telework.gov/.

5 Statistical data (population, GDP, literacy rates, etc.) are derived from UNCTAD databases (Sep. 3, 2020), available at $\mathrm{https}$ ://unctad.org/statistics.

6 English language proficiency rankings are derived from the EF English Proficiency Index (EF EPI) 2020 (Sep. 3, 2020), available at http://www.ef.com. 
Prior to the entry into force of amendments to the Labor Code of the Russian Federation in 2013, telework was often considered to be a form of home-based work; however, at present telework is referred to as an independent form of employment. ${ }^{8}$ As advantages of this employment form for employers, Russian economists point out cost savings and the possibility to attract labor from other regions and states. For employees, telework offers advantages in the form of flexible working hours, a reduction in commuting time, and the possibility to plan and perform labor functions independently.

At present, the telework regulation is specified in Chapter 49.1 of the Labor Code, which was introduced by Federal Law of 5 April 2013 No. 60-FZ. This chapter contains five articles and regulates the:

- concept of telework;

- peculiarities of the conclusion and modification of the telework contract terms and document exchange procedures;

- peculiarities of teleworkers' labor organization and protection;

- peculiarities of teleworkers' work and recreation modes;

- peculiarities of telework contract termination.

According to Chapter 49.1 of the Labor Code, telework has two essential characteristics. Firstly, it is performed by the worker outside the stationary workplace. Russian legislation distinguishes telework and home-based work. A teleworker does not necessarily have to work from home, their activities may also be of a travelling nature. Secondly, telework is carried out using information and communication technologies. It should be noted that Russian legislation, unlike U.S. and EU legislation, does not provide for the possibility of part-time telework. In fact, however, many workers (e.g. teachers) are partly involved in teleworking. ${ }^{9}$ It seems that one of the directions of improving the Russian legislation may be the introduction of the concept of full and part-time telework.

A significant part of the norms in Chapter 49.1 of the Labor Code specify procedures relating to electronic document flow. The parties to the employment contract may exchange not only paper documents but also electronic documents. The enhanced encrypted and certified digital signature (EDS) is required to give them legal effect. In practice, many Russian companies ignore these requirements, and

\footnotetext{
Томашевский К.Л. Компьютерное надомничество (телеработа) как одна из гибких форм занятости в XXI веке // Трудовое право в России и за рубежом. 2011. № 3. Vol. 32-36 [Kirill L. Tomashevsky, Computer Home-Based Work (Telework) as One of the Flexible Forms of Employment in the $21^{\text {st }}$ Century, 3 Labor Law in Russia and Abroad 32 (2011)].

8 Воробьёва О., ЛазареваИ. Особенности правового регулирования труда дистанционных работников // Балтийский гуманитарный журнал. 2018. Т. 7. № 2(23). Vol. 379-380 [Olga Vorobyeva \& Irina Lazareva, Features of Legal Regulation of Labor of Remote Workers, 2(23) Baltic Humanitarian Journal 379 (2018)].

9 Лютов Н.Л.Дистанционный труд: опыт Европейского Союза и проблемы правового регулирования в России // Lex Russica. 2018. № 10(143). C. 30-39 [Nikita L. Lyutov, Remote Work: The Experience of the European Union and the Problematic Aspects of Its Legal Status in Russia, 10(143) Lex Russica 30 (2018)].
} 
most workers do not have the necessary software and technical capability to use EDS. In addition, despite the conclusion of an electronic employment contract, the legislation establishes a requirement for the existence of the paper-based contract. It seems to us that in the conditions of the digital economy it is necessary to modernize the Labor Code norms and introduce paperless personnel document circulation.

It should be noted that in the legal literature at the time of its introduction Chapter 49.1 of the Labor Code was assessed quite optimistically. The several years that have passed since the amendments were introduced show that telework still remains in the 'grey sector' of the economy, and the current legislation has a large number of problematic and controversial points. Comparing the norms of Russian and American legislation, it can be concluded that compensation for the employee's expenses is the employer's right rather than a duty. As a rule, the employer does not include the compensation norms in employment contracts. Consequently, Russian teleworkers have a much lower level of rights protection. Russian legislation lags behind American legislation in regulating telework organizational issues, and it is true that in Russia the role of trade unions is significantly reduced in telework. ${ }^{10}$

In accordance with Article 312.4 of the Labor Code of the Russian Federation, the teleworker's work and recreation mode is established at their own discretion. The practice of applying the legislation poses many unanswered questions for the employee and employer, including those regarding compliance with the norms of the Labor Code for the working time duration, payment for overtime work, and night and holiday pay. So far, the current legislation does not address these questions. An example may illustrate this point. An employee appealed to the State Labor Inspectorate of the Rostov region in light of the following.. In accordance with his official duties, he was required to review online conferences within two days of their having taken place. One such online conference took place on a Saturday morning, and a review was done at the weekend and presented on Monday. The question posed here was: Is the employee eligible for an increased payment because he worked on Sunday?

The State Inspectorate reply stated that,

The employer does not have the need to maintain time records and fill in the time sheet for a teleworker. In the case, when a teleworker independently determines the work and recreation mode, there is no need for increased remuneration for the work performed during night, weekends, public holidays and overtime."

10 Нуштайкина К.В. Реализация права работников на социальное партнерство в условиях дистанционного труда // Вестник Пермского университета. Юридические науки. 2013. Вып. 3(21). С. 152156 [Ksenia V. Nushtaikina, Realization of the Right of Workers for Social Partnership in the Conditions of Remote Work, 3(21) Perm University Herald. Juridical Sciences 152 (2013)].

11 Ответы на вопросы Государственной инспекции труда по Ростовской области [Answers to Questions of the State Labor Inspectorate in the Rostov Region] (Sep. 3, 2020), available at https://git61.rostrud.ru/. 
The example presented shows that such an interpretation of the situation as a whole is valid from the point of view of the current legislation. However, from the employee's point of view, the use of telework leads to a significant reduction in the level of social protection.

There are difficulties in interpreting and applying labor laws when dismissing teleworkers. Part 1 of Article 312.5 of the Labor Code provides for the possibility of dismissal of a teleworker on the grounds provided for in the employment contract. This ground discriminates against teleworkers compared to most other categories of workers for whom there is no such ground for termination of the employment contract. There is no objective reason to identify such a basis for differentiating the work of teleworkers. ${ }^{12}$ Additionally, judicial practice has already accumulated a rather large number of disputes related to the peculiarities of teleworker dismissal because of absenteeism. Difficulties generally arise as to how to prove the presence or absence of a staff member in the workplace.

In general, Russian legislation regulates teleworking in a fragmented manner. The focus is made on procedural issues of the employment contract. Russian telework legislation is gender-neutral. A serious problem is the lack of telework-related statistics. The experience of introducing telework in state and local self-government authorities has not been developed in the Russian Federation yet. Russian labor law provides teleworkers with fewer guarantees than non-teleworkers. The Russian market is mainly dominated by national employers. Insufficient proficiency in English as well as digital skills are constraints in telework development.

\section{Telework in China}

Since December 2014, China's economy has been ranked number one worldwide in terms of GDP. The PRC is the world's leader in the production of most industrial products, including computers and telecommunications equipment. In 2018, the population of China exceeded 1.5 billion. By 2030, Chinas projected population will be 1.4 billion, so China is expected to lose the leadership in population size to India. The male adult literacy rate is $98.17 \%$, and the female literacy rate is $94.48 \%$. There are about 300 languages and dialects in China. The standard state language of the PRC is officially spoken only on the mainland. The Tibetan language has official status in the Tibetan Autonomous Region, and the Mongolian language in the territories of Inner Mongolia. Spoken languages in the Republic belong to at least nine families. In terms of English language proficiency, China ranks $36^{\text {th }}$ in the world. English proficiency is rated low. China's territorial development is heterogeneous. The eastern regions, as well as the areas along the sea coast, are considerably more developed. Guangdong Province has the lead in mainland China in the production of electronic, textile, food and pharmaceutical products and household appliances.

12 Lyutov 2018. 
The share of women in the Chinese labor market is high at over $40 \%$. Women's ability to work is seen as an important indicator of independence and gender equality. Most women work full-time because Chinese law does not provide any benefits for working mothers. The rapid economic development of the past two decades has led to the integration of rural women into the labor market.

The spread of telework in China is linked to the country's desire to improve its competitiveness in the global markets. Overpopulation and environmental pollution also increase the PRC's interest in developing teleworking. The active introduction of telework in China dates back to the early 2000s. According to one survey, the level of ICT-use by the Chinese was quite high at the time: $83 \%$ of companies used e-mail, and more than $85 \%$ of respondents had their own website. ${ }^{13}$

A few examples of successful experience in telework projects can be given. In hosting the 2008 Olympic Games, the Beijing Municipal Government asked stateowned enterprises to make the most of the opportunities of telework to reduce traffic congestion in the city. In 2010, in order to reduce emissions of harmful substances, the China National Development and Reform Commission (NRDC) selected Hubei Province to implement a pilot telework program. In addition, the Shanghai Government published ICT policy options for smart cities the same year. One of the program directions was to promote and support telework. Finally, the experience of Alibaba, which gave employees the opportunity to work from home, is the most indicative among commercial enterprises. Furthermore, a number of Chinese companies practice part-time telework when employees are allowed to reduce commuting in case of abnormal climatic conditions or epidemics.

The legal regulation of labor relations is regulated by the Labor Act (1994), the Employment Contract Act (2008) and the Employment Promotion Act (2007). The Employment Contract Act regulates part-time employment. It is this model that is most often used in telework. Remuneration for workers' labor in this case is paid on an hourly basis. Working hours do not exceed four hours per day, and weekly working hours do not exceed twenty-four hours. In part-time employment, the parties may conclude an agreement orally. A part-time employee may enter into an employment contract with one or more employers, but subsequently concluded employment contracts should not affect the performance of previously concluded employment contracts. In part-time employment, each side (employer and employee) may at any time notify the other side of the termination of the employment relationship. Upon termination of the employment relationship, the employer does not pay the employee severance pay. The hourly wage for part-time employment may not be less than the minimum hourly wage established by the government at the employer's location. The maximum frequency of calculation and payment of remuneration for

13 Nicholas Bloom et al., Does Working from Home Work? Evidence from a Chinese Experiment, 130(1) Quarterly Journal of Economics 165 (2014). 
part-time employment may not exceed fifteen days. Thus, part-time work is the main option for the registration of a teleworker. An employee may enter into several such contracts. A part-time employment contract significantly reduces the guarantees for workers, but allows for more flexible working arrangements.

Leading Chinese companies provide teleworkers with the same level of guarantees as non-teleworkers. This applies to wages, social insurance and benefits. Researchers note that in some cases the level of legal guarantees for teleworkers may even be higher. This is due, first, to sectoral peculiarities - the level of wages and guarantees in the telecommunications sector is higher than in agriculture. Second, as we noted earlier, international corporations often provide their teleworkers with a higher level of guarantees based on their experience and the higher requirements of U.S. and EU legislation.

Researchers note that the organization of telework in China should be based not solely on state regulation. The formation of an effective telework model should take into account cultural traditions. Long, Kuang \& Buzzanell indicate the need to cultivate guanxi. ${ }^{14}$ The guanxi effect is based on trust. Guanxi extends to different spheres of life of every Chinese person, but has a special force in the business world. Establishing strong ties is a tradition in Chinese society, and these ties can remain strong throughout a person's life. Telework, unlike traditional forms of employment, creates the problem of employee isolation. The problem of worker isolation has long been the focus of attention of Western researchers..$^{15}$ For China, due to cultural traditions, it matters much more. Surveys of teleworkers in China show that in addition to pay, working hours and cost compensation, it is important for them to establish common goals and develop common values with the employer. While non-teleworkers can cultivate guanxi in daily interactions at work, teleworkers face isolation due to the lack of workplace and interaction with colleagues. It is essential for Chinese workers to receive the approval of their boss and colleagues. This example shows that the legal regulation of telework should take into account the peculiarities of national culture and traditions.

Public opinion is another obstacle to the spread of telework in China. Due to culture and traditions, most Chinese believe that traditional office work is the only legitimate form of work in modern Chinese business conditions. The society treats telework with mistrust. It should be noted that this situation was also common in Western countries at the early stages of telework distribution. It was perceived as something not serious and even fraudulent. The gradual increase in the number of teleworkers, and the development of legislation, has led to the perception of telework as an effective form

14 Ziyu Long et al., Buzzanell Legitimizing and Elevating Telework, 27(3) Journal of Business and Technical Communication 243 (2013).

15 Arora Shikha, Does Workplace Isolation Matter? Examining the Impact of Workplace Isolation on Telecommuter Work Engagement (Melbourne, FL: Florida Institute of Technology, 2012). 
of employment in Western countries. In developing countries, including China, such a position is being formulated with a considerable delay.

When studying the experience of organizing telework in China, it is important to note that many Chinese workers assess the advantages of telework in a different way compared to representatives of Western countries. Thus, European and American workers see the advantage of telework in reducing commuting time. Chinese workers note in their interviews that they spend the saved time on establishing deeper and more trustworthy relationships with customers. Telework is viewed by the Chinese through the lens of work ethic.

China's experience shows that the development of telework is largely determined by cultural factors. With a large population and deep integration into the global economy, China could become the largest market with millions of teleworkers. At the state level, China is aware of the importance of telework to mitigate environmental problems. China is Russia's largest economic partner and close neighbor. Within the framework of BRICS, it is necessary to look for opportunities to develop telework in order to strengthen Russian-Chinese relations.

\section{Telework in India}

India ranks second in BRICS in terms of population - India's population exceeded 1.38 billion in 2018. By 2030, India's projected population will exceed 1.5 billion. The adult male literacy rate is $80.95 \%$, and the female literacy rate is $62.84 \%$. More than $\mathbf{2 0 0}$ million people are illiterate in India, which exceeds the entire population of Russia. India has many megalopolises with more than 10 million inhabitants. The most populous include Mumbai, Delhi, Bangalore, Calcutta and Hadarabad. India is characterized by significant differences in territorial development. Major cities develop as modern megalopolises, while most of the population continues to reside in the provinces. Most of the population is employed in agriculture. The state languages are English and Hindi. Due to ethnic diversity, there are more than 2,000 dialects in India. India ranks $27^{\text {th }}$ in the world in terms of English proficiency, which varies significantly. There are virtually no language barriers among the educated part of the society, while the people of the countryside mostly speak one of the many dialects.

India represents the most promising market for telework job openings in BRICS. A particularly large number of job openings are placed by U.S. employers. A number of factors account for the main reasons why the United States is active in India's labor market. First, India, on a par with China, is one of the largest labor markets. Second, as already alluded to, highly skilled workers do not face a language barrier, which facilitates their integration into international corporations. Third, the active development of the telecommunications sector in India and public investment in the development of information technologies provide a large number of qualified and trained information technology (IT) specialists. Low pay explains the high demand for Indian programmers among American companies. 
Bangalore's experience is the most successful in terms of developing telework. The scientific literature even formulated the concept "Bangalore Phenomenon." The city of Bangalore is often referred to as the Indian Silicon Valley. The economic breakthrough in Bangalore was made possible by the fact that in 1991 Manmohan Singh, the Finance Minister of India, gradually began to open the Indian economy to foreign investment.

In the late 1990s, due to "the Year 2000 problem" (aka Y2K bug), thousands of programmers were needed across the globe to reconfigure computer systems. India was able to provide sufficient numbers of qualified specialists to software manufacturers (mainly from the United States). India reached a new level as a host country of outsourcing, allowing a large number of Indians to join the single global market for goods and services.

Infosys Technologies is among the most famous and successful IT companies in India. The company is headquartered in Bangalore. In 1999, it became the first Indian firm to launch an IPO in the United States. The Bangalore Phenomenon can be an example for all of the BRICS countries. The key factors of Bangalore's success in developing telework are attributed to the combination of legal, geographic and infrastructure factors. Investors from other countries are attracted by the presence of highly qualified specialists, a favorable tax regime, as well as a special culture similar to the culture of Silicon Valley in the United States. Educational institutions have played a significant role in Bangalore's success as a telework center in India. Historically, Bangalore has been home to the best universities that focus on UK standards and training experience. Effective training for teleworkers includes both technical skills and soft skills. Among the soft skills required by teleworkers, Indian researchers consider the skills of planning and independent work organization. Government efforts are now focused on replicating Bangalore's success in other major Indian cities, such as Calcutta and Mumbai.

Telework is actively introduced in the field of information technologies and communications, in the media, book publishing, education, trade and even medicine. It is necessary to emphasize once again the fact that the main employers offering telework in India are companies from the United States and the European Union. The huge difference in wages allows international companies to achieve substantial savings. For example, India has created many jobs in telemedicine and medical data processing. ${ }^{16}$

While in the United States the annual income of a specialist who processes medical data is more than $\$ 25,000$ a year, in India the salary does not exceed $\$ 1,500$ a year. The shift of jobs from developed countries to India is also due to the fact that the population in developed countries is gradually ageing. At the same time,

16 Ernesto Noronha \& Premilla D'Cruz, The Dynamics of Teleworking: Case Studies of Women Medical Transcriptionists from Bangalore, India, 12(2) Gender, Technology and Development 157 (2008). 
India's job market is dominated by young specialists, who can master new digital skills much easier. The high share of young people in the labor market determines India's attractiveness to foreign employers. According to Swasti Mitter, the creation of telework in India reduces staff costs five to ten times. ${ }^{17}$

The main obstacle to the development of telework in India is the high poverty rate. Many towns and rural areas in India still lack stable electricity supply. One of the most important state initiatives was the creation of telecenters - office buildings with all of the necessary equipment in which points of collective access to the Internet were created. This has led to significant progress in the field of information technology.

Significant shortcomings in the legal regulation of telework in India are observed regarding the protection of teleworkers' rights and their workplace safety. As noted earlier, this situation is also common in the Russian Federation. Indian lawyers insist on ensuring equal rights of teleworkers and non-teleworkers in the field of health care, regular medical examinations, eyesight checkups and workplace safety.

In considering the gender dimension of telework development, a high level of gender inequality must be taken into account. As noted earlier, almost $40 \%$ of women in India are illiterate, and unable to use electronic means of communication. They do not have the skills that would allow them to be involved in telework. In addition, the spread of telework is prevented by a large number of children in the family, overpopulation and lack of necessary infrastructure. As Swasti Mitter notes, telework is available mainly to educated women from well-off families. ${ }^{18}$ The level of gender inequality in telework in India remains high. Surveys of Indian women show that remote work is not always seen as an advantage. Even mothers with disabled children point out that the main disadvantage of telework is isolation, lack of communication and lack of support from the society.

Women's involvement in telework varies significantly across industries. Thus, among programmers, the proportion of women does not exceed $20 \%$. At the same time, international airlines, using telework in back-offices and call-centers, mainly assign such work to women. A number of initiatives have been taken to reduce gender inequality in India. For example, SNDT Women's University and the National Center for Software Technology have been conducting a special course on improving computer literacy of women since 2000. Special attention is paid to the training of rural women. As measures to reduce gender inequality, it is proposed to provide women with preferential educational loans and subsidies for the purchase of computer equipment and software.

Thus, India has successful experience in creating telework in the IT sector. The Bangalore Phenomenon is of interest to all of the BRICS countries. India is a country

\footnotetext{
17 Swasti Mitter, Teleworking and Teletrade in India: Combining Diverse Perspectives and Visions, 35(26) Economic and Political Weekly 2241 (2000).

18 Id.
} 
that is characterized by a high level of gender inequality. Telework is mainly targeted at highly skilled workers. Indian workers' competitive advantage is fluency in English. The largest employers creating tele-jobs are U.S. and EU residents. The influence of cultural factors and traditions results in the heterogeneous spread of telework in India in both in sectoral and in territorial terms.

\section{Telework in Brazil}

Brazil ranks $3^{\text {rd }}$ in BRICS in terms of population. The number of Brazil's residents in 2018 amounted to 215 million people. By 2030, Brazil's projected population will rise to 225 million. Life expectancy is 72 years. That is higher than the average world life expectancy, which is around 71 years. The literacy rates for both men and women are around $92 \%$. The state language is Portuguese. The level of English proficiency is low - the country ranks only 41 st in the world, the worst result for any BRICS country.

Brazil has a relatively high level of urbanization. According to the Brazilian Institute of Geography and Statistics (BIGS), eight out of ten Brazilians live in cities. The largest cities are Sro Paulo, Rio de Janeiro, Brasilia, Belo Orizonti, El Salvador and Fortaleza. From a territorial point of view, Brazil has an important distinctive feature: the great Amazon River. The Amazon region is sparsely populated and difficult terrain. The most developed industry is concentrated in the south and south-east of the Brazil. The northeast is the country's poorest region.

Over the past twenty years, Brazil has created a large number of teleworkers. The country has started to generate statistical information on the spread of telework, among other methods, through conducting surveys of employers. According to IBGE, using information collected in the last census of 2010 , approximately $23 \%$ of Brazilians (about 20 million people) have experience in home-based work, including telework via the Internet. ${ }^{19} \mathrm{~A}$ study conducted by Brazil's Ministry for Home Affairs with institutional support from SOBRATT (Brazilian Society of Challenges of Telework in Brazil) found that of the 325 companies surveyed, $68 \%$ used telework in one form or another. Some companies provided part-time telework to their workers, about $40 \%$ organized home-based jobs for employees. However, only $60 \%$ of those companies that actually used telework enshrined this activity formally in their local corporate agreements The remaining $40 \%$ used telework without amending contracts and local corporate agreements. Interestingly, tele-jobs are created not only in the commercial sector, but also in the sphere of public administration.

The legislative regulation of telework in Brazil has undergone a significant change over the past few years. In 2011, the Consolidation of Labor Laws (CLT) introduced Article 11, which enshrined equality of rights for teleworkers and non-teleworkers.

19 IBGE: Censo Demogr6fico (Sep. 3, 2020), available at http://www.ibge.gov.br/home/estatistica/ populacao/censo2010/default.shtm. 
However, in 2017, the CLT amended Article 62. According to this amendment, teleworkers are not subject to time control regulations. In actual fact, this resulted in teleworkers'losing their right to overtime pay. The severity of the issue of overtime accounting and payment is evidenced by the research conducted by Brazilian economists. In Boonen's survey, $97 \%$ of teleworkers work more than the standard eight hours a day, compared to $57 \%$ for non-teleworkers. The same survey indicates that $49 \%$ of teleworkers work more than thirteen hours a day. ${ }^{20}$ For non-teleworkers, such a situation does not arise due to direct prohibition and strict fines.

Studies also point to such issues as transferring costs from an employee to an employer. Brazilian employers do not seek to pay the costs of a teleworker for communications, Internet access service, purchases of equipment and electricity utility costs. ${ }^{21}$ In 2017, legislation included the norm that the procedure for reimbursement of a teleworker's costs relating to communications and workplace equipment is determined by an individual employment contract. The employer is also obliged to conduct health and safety briefings. However, it is not clear how the employer will monitor the implementation of these instructions. On the basis of a comparative legal analysis, we can conclude that the norms of Russian and Brazilian legislation in the field of telework regulation are significantly similar. Despite the sufficient prevalence of telework, researchers note most issues are poorly studied, including the protection of labor rights and gender equality.

\section{Telework in South Africa}

South Africa is the smallest BRICS country by population. In 2018, the number of residents amounted to 57 million people. South Africa is one of the most nationally diverse countries in Africa and has the largest proportion of white population on the continent. One of the most pressing demographic problems in the country is the reduction of the white population due to emigration. Life expectancy at birth (for both sexes) in South Africa is 49.3 years. This is the lowest figure for any of the BRICS countries. By 2030, the projected population of South Africa will exceed 64 million. The male adult literacy rate is $95.51 \%$, and the female literacy rate is $93.13 \%$. There are eleven official languages, including English, under the Constitution of South Africa. English language proficiency is the highest in BRICS, and the country ranks $8^{\text {th }}$ worldwide.

South Africa is characterized by a high stratification of the population. About $15 \%$ of the population live in the best conditions, while about $50 \%$ (mostly black) are very poor. Not all residents have access to electricity and clean water, and poor sanitation in many settlements contributes to the spread of various diseases. About

\footnotetext{
20 Eduardo Boonen, As v6rias faces do teletrabalho, 2/3E G Econ e Gestro 106 (2002).

${ }_{21}$ Isabel Costa, Teletrabalho: subjugazгo e construзго de subjetividades, 41(1) Rev Adm Pъblica 105 (2007).
} 
17 million people live below the poverty line, and about 11 million of them live in rural areas. The national unemployment rate is about $40 \%$.

South African researchers note that telework is not sufficiently developed yet. ${ }^{22}$ As in all of the BRICS countries, there is a lack of statistical information available. A characteristic feature of South Africa is persistent gender and racial inequality. Racial differences are still widespread, while $82 \%$ of white South Africans have a phone in their home, only $18 \%$ of black South Africans have a phone connection in their homes. ${ }^{23}$

The question of how to ensure equal access to telework for rural women is particularly acute. Women's low income, due to the lack of access to education, formal employment, social security and public employment programs, has marginalized women in South Africa.

The African Information Society-Gender Working Group (AIS-GWG) has identified a range of issues that need to be addressed in order to reduce gender and racial inequalities in the use of IT technologies. The most important regulatory documents are the White Paper on Telecommunications and the Telecommunications Act of 1996. The White Paper on Telecommunications states:

Besides referring to those who were disadvantaged by the apartheid system in the past, the term "disadvantaged" also applies to those South Africans who have been historically disadvantaged through discrimination on the grounds of gender and/or disability. In the context of telecommunications, the severe disadvantage experienced by the members of rural communities under apartheid should receive special attention. ${ }^{24}$

One mechanism for developing telework, as well as ensuring equal access to information technologies in South Africa, is the establishment of telecenters by the Universal Service Agency. The evaluation of the effectiveness of this initiative receives conflicting assessments. According to the developers, telecenters should allow residents of rural areas and remote areas of South Africa to do telework. The program has received significant budgetary funding. However, a study by Aki Stavru and Peter Benjamin shows that many of the created telecenters do not function. ${ }^{25}$ The

22 Nicholas Baard \& Adŭle Thomas, Teleworking in South Africa: Employee Benefits and Challenges, 8(1) SA Journal of Human Resource Management 298 (2010).

23 Alison Gillwald et al., Gender Assessment of ICT Access and Usage in Africa, Volume One 2010 Policy Paper 5 (Sep. 3, 2020), available at https://www.ictworks.org/sites/default/files/uploaded_pics/2009/Gender_ Paper_Sept_2010.pdf.

24 National Integrated ICT Policy White Paper (Sep. 3, 2020), available at https://www.dtps.gov.za/images/ phocagallery/Popular_Topic_Pictures/National_Integrated_ICT_Policy_White.pdf.

25 Peter Benjamin et al., Telecentre 2000: Synthesis Report (Johannesburg: DRA-Development and LINK Centre, 2000). 
main reasons for the low efficiency of telecenters consists in the lack of professional training, and residents' low digital literacy.

Under licensing requirements, each company is required to contribute $1 \%$ of the pay fund to the Human Resource Development Fund. The Employment Equity Act requires that on the national scale companies seek gender and racial equality. Both of these pieces of legislation demonstrate the strength of trade unions. However, they are often criticized for creating an unfriendly environment for investors and unnecessary regulatory barriers.

Despite the fact that South Africa is creating tele-jobs for women, gender inequality remains acute. This is reflected in the fact that even if equal access to jobopenings is ensured, in the field of telework women occupy mainly low-paying positions without career prospects. As has been noted by Alison Gillwald:

If 1000 women are employed in a company of 2000 and all are domestic workers or secretaries, this is unlikely to be a contributing factor to gender equity. ${ }^{26}$

Another problem is that in South Africa residents speak not only English, but also many dialects. Accordingly, proficiency in English often acts as a necessary requirement when providing telework. Sara Macharia points out:

The relevance of the information being disseminated [on the Internet] ... may be readily accessible but sometimes the materials being transmitted may appear too technical, too difficult to understand or having no bearing to the African situation, therefore causing users in the region to ignore such material. $^{27}$

This problem is common in the BRICS countries. The telework phenomenon consists in the fact that the generated jobs are designed mainly for educated and skilled professionals. This fact can only increase inequality. The solution to inequality is to improve overall education, digital literacy and knowledge of English as a universal language in business communications.

The analysis of scientific publications identified an interesting area which is currently being studied mainly by researchers from South Africa. This is related to the BYOD concept. The concept of "bring your own device" (BYOD) describes a situation where employees use their own equipment (computers, laptops, mobile phones,

26 Gillwald et al., supra note 23.

27 Sara Macharia, Presentation to the Expert Group Meeting, WomenWatch Global Information through Computer Networking Technology in the follow-up to the Fourth World Conference on Women, 26-28 June 1996, NYC U.N. Division for the Advancement of Women, UNIFEM \& INSTRAW (mimeo). 
tablets, office equipment, etc. $)^{28}$ instead of stationary workplaces and equipment provided by the employer. By using the employee's equipment, the employer's costs are significantly reduced. It decreases costs for office rental, for purchases of equipment, electricity usage and communications services. As we have repeatedly stressed in previous studies, there is actually a transfer of costs to the employee. ${ }^{29}$ At the same time, such policies lead to increased threats in the field of computer security, protection of intellectual rights and personal data, health and safety issues. South Africa is particularly interested in BYOD due to the high growth rate in the introduction of mobile devices in business practices. Against the explosive increase in the use of workers' mobile devices, most employers in South Africa do not have a clear idea of how to develop BYOD policies and minimize emerging risks.

The European Union Network and Information Security Agency (ENISA) guide to BYOD risk management focuses on owners rather than devices. The United States National Institute of Standards and Technology (NIST) (2016) published the 'User's Guide to Telework and Bringing Your Own Device Security' which presents specific recommendations to address security concerns relating to BYOD. Accordingly, securing a device used for BYOD includes:

- using special programs (antivirus software, personal firewalls, filtering spam and web content, as well as blocking pop-ups);

- limiting PC use by having a separate user account for each person;

- ensuring that updates are regularly applied to the operating system and core applications;

- switching off unnecessary network features on PCs and secure configuration of wireless networks;

- configuring core applications to filter content and stop other activities that may be malicious;

- installing and using only well-known and reliable software;

- configuring remote access software based on the organization's requirements and recommendations;

- maintaining PC security on a continuous basis, for example by changing passwords regularly and checking software health periodically.

This makes it possible to conclude that South Africa's experience is of great value to all of the BRICS countries. South Africa's historical experience relates to the recognition of gender and racial inequality and active policies to remedy this

28 Ivan Veljkovic \& Adheesh Budree, Development of Bring-Your-Own-Device RiskManagement Model: Case Study From a South African Organisation, 22(1) Electronic Journal of Information Systems Evaluation 1 (2019).

29 Чудиновских М.В. Регулирование дистанционного труда в странах Евразийского экономического союза // Евразийская адвокатура. 2018. № 4(35). Vol. 109-111 [Marina V. Chudinovskikh, Regulation of Distance Work in the Eurasian Economic Union, 4(35) Eurasion Advocacy 109 (2018)]. 
serious matter. In other BRICS countries, inequality issues also occur, but they are not recognized so openly. The absence of public initiatives for equality in telework can lead to "digital inequality." South Africa's experience shows that the construction of telecenters does not solve the problem of generating telework for the poorest people in rural areas. Increasing the availability of mobile computer equipment and its use in telework forms the need to conceptualize the BYOD issue.

\section{Conclusion}

The study concludes that the BRICS countries are still in the early stages of establishing an integrated legal regulation of telework. Telework itself is developing very rapidly, and residents of the BRICS countries receive employment opportunities in international companies. Telework regulation should not be limited to labor law. The issue of equality of access to telework job openings, regardless of sex, race, nationality or place of residence, is of great importance. Telework can contribute to a more uniform development of rural and remote areas.

Based on the findings of the study, we propose a set of measures to improve state policy in the field of telework, including its legal regulation.

1. Currently, the BRICS countries lack up-to-date statistical information on the spread of telework. ${ }^{30}$ It seems necessary to collect telework statistics, including sexdisaggregated data. Such information should serve as a basis for developing telework policies. This information should be published and made available to the public. It is necessary to maintain records of employers providing telework opportunities. The experience in such accounting already exists in the United States and the EU countries.

2. Teleworkers should be informed about the peculiarities of the telework legal regulation, their rights and duties. In the developed countries, state telework portals that provide information about legislative acts, methodological recommendations for employees and employers, materials of scientific research and surveys are being set up.

3. The protection of teleworkers' rights should be facilitated by the establishment of trade unions. In view of the territorial separation of teleworkers, it may be necessary to change the legal and regulatory framework for joining a trade union and conducting collective negotiations.

4. The peculiar feature of telework consists in the use of tele-workplaces. Teleworkers should be compensated for the costs incurred in the performance of their

30 Natalia Tonkikh et al., Assessment of Female Telework Scope in the Conditions of Digital Economy, Proceedings of the $1^{\text {st }}$ International Scientific Conference "Modern Management Trends and the Digital Economy: From Regional Development to Global Economic Growth" (MTDE 2019) (Sep. 3, 2020), available at https://www.atlantis-press.com/proceedings/mtde-19/125908810. 
job functions, namely equipment, communications, electricity utility costs, office supplies and other work-related expenses.

5. The legislation of the BRICS countries has little regulation of issues related to teleworkers' health and safety protection. Teleworkers may be open to certain harmful factors. Teleworkers should be subject to the basic regulations, rules and instructions adopted in the field of occupational health and safety. To the extent possible, these guidelines should be translated into languages spoken by teleworkers. It should be the responsibility of employers to inform teleworkers of all the hazards associated with their work and the precautions to be taken, and to train them properly if necessary. The teleworkers' duties should include the implementation of prescribed safety and health measures, the adoption of reasonable precautions with regard to their own safety and health, as well as the safety and health of others, including family members.

6. The issue of teleworkers' recreation mode requires further study. The studies conducted in many countries indicate that teleworkers experience a significant excess of working time. The increase in teleworkers' working time may be determined by the difference in time zones, as well as by the need to respond promptly to tasks of employers or clients. The time limit for a teleworker to perform a task should not deprive him or her of the possibility to have a daily or weekly holiday comparable to that enjoyed by other workers.

7. Teleworkers should enjoy the same protection as other workers with regard to termination of employment. At present, however, some legislation in force, for example in the Russian Federation, allows for the possibility of termination of an employment contract with a teleworker "on the grounds provided for in the employment contract." In fact, teleworkers are becoming more vulnerable in this regard than nonteleworkers.

8. At the level of each of the BRICS states, it is necessary to develop a state program for telework development. The program should include issues of informing the society about the opportunities, advantages and peculiarities of telework. Gender equality requires the development of digital literacy programs. This is particularly relevant for rural areas. Active inclusion in the world's labor market requires proficiency in foreign languages, especially English. Government programs may include training courses, including those delivered on the basis of distance-learning technologies. The creation of conditions for telework development can be facilitated by the provision of concessional loans or subsidies for socially vulnerable segments of the population for the purchase of computer equipment, phones and software.

9. Telework requires creating a special corporate culture and availability of soft skills. It is reasonable to deliver cultural courses at BRICS educational institutions. Such experience can be useful for international teams and implementation of joint projects. 
10. In order to manage telework and protect it against cyber threats, employers should develop local corporate agreements, including those within the framework of the BYOD concept. A clear BYOD policy is an important step toward managing privacy and security in organizations. Employees using BYOD must follow appropriate procedures when accessing and using information resources. The developed information security policy should be enshrined in local corporate agreements, and teleworkers should be trained. From the perspective of Russian labor law, employers are currently obliged to train employees in the field of labor protection. With the development of telework, it is possible to predict the need to establish norms for compliance with information security not at the level of an employment contract with an employee, as now enshrined in Article 312.3 of the Labor Code of the Russian Federation, but in a local normative act.

Thus, the BRICS countries are still in search of an optimal model for regulating telework. The creation of optimal legal conditions can contribute to deeper integration of the countries, and intensification of their joint economic and scientific projects.

\section{References}

Лютов Н.Л. Дистанционный труд: опыт Европейского Союза и проблемы правового регулирования в России // Lex Russica. 2018. № 10(143). С. 30-39 [Lyutov N.L. Remote Work: The Experience of the European Union and the Problematic Aspects of Its Legal Status in Russia, 10(143) Lex Russica 30 (2018)].

Нуштайкина К.В. Реализация права работников на социальное партнерство в условиях дистанционного труда // Вестник Пермского университета. Юридические науки. 2013. Вып. 3(21). С. 152-156 [Nushtaikina K.V. Realization of the Right of Workers for Social Partnership in the Conditions of Remote Work, 3(21) Perm University Herald. Juridical Sciences 152 (2013)].

Baard N. \& Thomas A. Teleworking in South Africa: Employee Benefits and Challenges, 8(1) SA Journal of Human Resource Management 298 (2010). https://doi.org/10.4102/ sajhrm.v8i1.298

Long Z. et al. Buzzanell Legitimizing and Elevating Telework, 27(3) Journal of Business and Technical Communication 243 (2013).

Noronha E. \& D'Cruz P. The Dynamics of Teleworking: Case Studies of Women Medical Transcriptionists from Bangalore, India, 12(2) Gender, Technology and Development 157 (2008). https://doi.org/10.1177/097185240801200201

Veljkovic I. \& Budree A. Development of Bring-Your-Own-Device Risk Management Model: Case Study From a South African Organisation, 22(1) Electronic Journal of Information Systems Evaluation 1 (2019). 


\section{Information about the authors}

Marina Chudinovskikh (Yekaterinburg, Russia) - Associate Professor, Department of Public Law, Ural State University of Economics (8 Marta St., Yekaterinburg, 620990, Russia; e-mail: chudinovskihmv@usue.ru).

Natalia Tonkikh (Yekaterinburg, Russia) - Associate Professor, Department of Labor Economics and Personnel Management, Ural State University of Economics (8 Marta St., Yekaterinburg, 620990, Russia; e-mail: tonkihnv@usue.ru). 